\title{
Forage Dry Matter Yield and Nutritive Value of the Natural Pasture of Umbulo Wacho Watershed, Southern Ethiopia
}

\author{
Tegene Negesse ${ }^{1 *}$, Senbeto Funte ${ }^{2}$ and Adugna Tolera ${ }^{1}$
}

${ }^{1}$ Animal and Range Science Department, Hawassa University, P O Box 336, Hawassa, Ethiopia

${ }^{2}$ Ministry of Agriculture, Southern Nations, Nationalities and Peoples Regional State, P O Box 1440, Hawassa, Ethiopia

\begin{abstract}
The biomass production and nutritive value of the natural pasture of Umbulo Wacho watershed in Southern Ethiopia were studied. The upper and medium altitudinal zones had an open area and areas closed for 2, 3 and 4 years and the lower altitude had an open area and an area closed for 2 years. In each of the open and closed areas, three sites were selected ( 9 in open, 21 in closed) at each of which exclusion cages (30) were fixed. The re-growths of forage samples were cut at 30 days interval from May up to November from the exclusion cages. The overall dry matter (DM, \%), organic matter $(\mathrm{OM})$, crude protein $(\mathrm{CP})$, neutral detergent fiber (NDF), acid detergent fiber (ADF), acid detergent lignin (ADL), ash, calcium (Ca) and phosphorus (P) contents of the forages were $30.8,83.9,12.7,66.7,32.6,4.5,16.2,0.6$ and $0.3 \%$, of the $\mathrm{DM}$, respectively; in vitro DM digestibility (IVDMD) was $72.1 \%$ and DM yield (DMY) was $71.34 \mathrm{~g} / 1.21 \mathrm{~m} / 30 \mathrm{~d}(0.59$ tones $/ \mathrm{ha} / 30 \mathrm{~d})$. The natural pasture $(117.1 \mathrm{ha})$ produced 829.07 tones of DM/year $(0.59 * 117.1 * 12)$ which can only meet $8.20 \%$ of the total DM requirement $(10,107.11$ tones/year) of the tropical livestock unit (4431) found in the watershed. Closing an area for long duration decreased $(\mathrm{P}<0.01) \mathrm{CP}, \mathrm{P}, \mathrm{DMY}$ and IVDMD, but increased ADF and ash. Advance from the rainy season towards the dry period reduced $(\mathrm{P}<0.01) \mathrm{DM}, \mathrm{DMY}, \mathrm{CP}, \mathrm{ADF}$, ash and $\mathrm{P}$. With increasing altitude, DM increased $(\mathrm{P}<0.01)$ but DMY, NDF and $\mathrm{P}$ decreased. The IVDMD was positively correlated with DMY and negatively correlated with NDF and ash $(\mathrm{P}<0.05)$. The interactions among closed or open areas, sampling time and altitude were significant $(\mathrm{P}<0.05)$ for most of the nutrient content and yield parameters. The forages could be cut twice (middle and end of the rainy season) when the nutrient contents are optimal. For integrated and sustainable use of forages in the watershed, further study in improvement of quality and utilization is suggested.
\end{abstract}

Keywords: Forage; Dry Matter; Watershed; Natural Pasture

\section{Introduction}

Livestock plays an important role in the livelihood of the farmers in the Umbulo Wacho Watershed in Southern Ethiopia. The watershed suffers from severe shortages of water and feed. Due to the rapidly increasing human population, cropping is expanding and grazing areas are shrinking, the available natural pastures are excessively stocked with animals and are thus overgrazed. Although natural pasture is one of the feed sources of livestock in the watershed, its productivity is gradually decreasing because of overstocking and soil erosion. Livestock exclusion was thus necessary for stabilizing the area. Improvement in total yields and feed value of forages in closed areas is possible by shifting the use of forages from grazing to cut and carry (Tsige, 1999).

Umbulo Wacho was selected for this particular study because it is among the areas that have distinctive watershed. Large closed areas due to soil degradation and shortage of livestock feed were among the top priority problems of the area according to a diagnostic survey conducted in 2003. Natural pasture is one of the feed resources of animals in the watershed, however, as it is the common case elsewhere in Ethiopia (Aune et al., 2001), its productivity is gradually decreasing because of overstocking with the resultant overgrazing. This is particularly serious during the drier part of the year with substantial reduction in the performance of livestock (Legesse, 2008).

Biomass is regarded as an important indicator of ecological and management process in the vegetation (URL, 2001). Above ground biomass is commonly available to large herbivores and below ground biomass is very important for plant functions (Holechek et al., 1998).
Direct harvesting is considered the most reliable method of determining the above ground biomass (Snyman, 1993) and biomass is best expressed in terms of dry matter yield (Herlocker, 1999). Low DM degradation was recorded at heavily degraded range sites, but higher DM yield was exhibited in enclosures where the grazing intensity was low (Ahmed, 2003; Admasu, 2006). Dry matter biomass in enclosures was significantly higher than in communal grazing lands because the later are overgrazed and less productive forages might be related with overgrazing (Abule, 2003; Amaha, 2006).

Despite the wide use of indigenous forages by farmers, biomass production of the natural pasture and availability of other feed resources of the watershed have not been properly studied up to now. Estimation of forage biomass production and assessment of forage quality variables were, therefore, important for making adjustment on stocking rate and taking decisions of pasture management.

The objective of the study was therefore to measure the biomass production and nutritive value of forages in the natural pasture of the closed and open areas of the watershed.

\section{Materials and Methods 2.1. Description of the Watershed}

The watershed $\left(38^{\circ} 17^{\prime} \mathrm{E}, 7^{0} 01^{\prime} \mathrm{N}\right)$ lies between 1500 and $2300 \mathrm{~m}$. a. s. l. and receives an annual rainfall of 1067 $\mathrm{mm}$. Rainfall is bimodal and unpredictable. The dry season lies between November and May, March and May being the driest months. The rainy season includes April, June, July, August and September, sometimes extending up to October or November. Frost is common in the 
Tegene et al.

area and it occurs for a short duration of time between October and November and damages legume species and leaves of young enset which causes scarcity of livestock feed. Crop and livestock production are the main activities in the watershed. Cattle, sheep, goats, donkeys and chickens are major livestock species kept (Diagnostic Survey Report, 2003; Senbeto, 2006).

Land degradation and moisture stress are severe problems and the vegetation cover has been denuded, soil eroded and wide and deep gullies have formed. Land management through conservation-based rehabilitation of the watershed was undertaken in an attempt to address the problems. Accordingly, large degraded areas of land were closed from grazing for rehabilitation and management has been entrusted to the community.

There is a significant shrinkage of grazing areas and existing natural pastures are heavily populated with livestock and overgrazed. Thus, especially during the dry season, animals are not able to meet even their maintenance nutrient requirements and lose substantial amounts of their body weight.

\subsection{Experimental Design, Forage Sampling Technique, Weighing and Processing}

As shown in Table 1, the study area was stratified into three altitudinal zones, high $(\mathrm{H}$, above $1750 \mathrm{~m}$. a. s. 1 , plain), medium (M, from 1650 to $1750 \mathrm{~m}$. a. s. 1, steep slope), and low (L, below $1650 \mathrm{~m}$. a. s. 1, flat land). The high and medium altitudinal zones were blocked into open and closed, and the closed areas were closed for 2 , 3 and 4 years. Similarly, the low altitude was blocked into an open and a closed area (closed for 2 years only). In each of the open and closed areas of the altitudinal zones, three sites were selected which gave a total of 30 sampling sites at each of which exclusion cages were fixed. Cages of each stratum were placed 500 to $600 \mathrm{~m}$ apart depending on the size of the area. The dimension of the exclusion cages were $1.1 \mathrm{~m} \times 1.1 \mathrm{~m} \times 1 \mathrm{~m}(\mathrm{~L} \times \mathrm{W} \times$ $\mathrm{H})$, and were firmly fixed in the ground to prevent them from being moved by animals. Each cage in the open areas was moved to new places around the selected site after every cutting, in order to take account of the effect of urine and feces excreted by grazing animals. It was
East African Journal of Sciences Volume 4 (1) 1-10 rotated in a four to five meter radius from the center of the initial position of the cage in a clockwise direction to minimize personal bias. However, the cages in the closed areas were not rotated. The forages in the cages in both the open and closed areas were cut at an interval of 30 days.

The first sample was taken in May 2005, and from then on at an interval of 30 days. Seven consecutive samplings were taken from May to the end of November. The entire herbage from individual exclusion cages was manually cut at ground level using scissors and weighed. The freshly collected samples from individual exclusion cages were separated into grasses, legumes and others and weighed. Each type of herbage from individual cages was then thoroughly mixed and a representative sample of $200 \mathrm{~g}$ was taken and put into a carefully labeled plastic bag, and then transported to Animal Nutrition laboratory of Hawassa College of Agriculture. The samples were dried at $65{ }^{\circ} \mathrm{C}$ for 48 hours. The dried samples were ground to $1 \mathrm{~mm}$ size and stored in airtight plastic bags until they were subjected to chemical analysis and an in vitro DM digestibility.

The forage samples collected were grouped into four sampling times May, June, July to September and October to November based on rainfall distribution and forage biomass productivity (Table 2). The samples collected during July, August and September were pulled for each cage and the same was done for samples collected during October and November and average monthly DMY of forages from each cage were calculated.

\subsection{Chemical Analysis}

Determination of DM and total ash contents was carried out using the procedures of AOAC (1990). Nitrogen (N) and phosphorus $(\mathrm{P})$ contents were determined by autoanalyzer and crude protein $(\mathrm{CP})$ was calculated as $\mathrm{N} \times$ 6.25. Neutral detergent fiber (NDF), acid detergent fiber (ADF) and acid detergent lignin (ADL) were analyzed according to Van Soest et al. (1991). Calcium (Ca) was analyzed by atomic absorption spectrophotometer (Perkin, 1982).

Table 1. The design of the distribution of cages used for the assessment of biomass production of Umbulo Wacho watershed natural pasture.

\begin{tabular}{|c|c|c|c|c|}
\hline \multirow[b]{3}{*}{ Altitudinal zones (m. a. s. l) } & \multicolumn{4}{|c|}{ Area conditions } \\
\hline & \multirow[b]{2}{*}{ Open } & \multicolumn{3}{|c|}{ Closed (years) } \\
\hline & & 2 & 3 & 4 \\
\hline \multirow{3}{*}{$\operatorname{High}(>1750)$} & Cage $_{1}$ & Cage $_{1}$ & Cage $_{1}$ & Cage $_{1}$ \\
\hline & Cage $_{2}$ & $\mathrm{Cage}_{2}$ & $\mathrm{Cage}_{2}$ & $\mathrm{Cage}_{2}$ \\
\hline & $\mathrm{Cage}_{3}$ & $\mathrm{Cage}_{3}$ & $\mathrm{Cage}_{3}$ & $\mathrm{Cage}_{3}$ \\
\hline \multirow{3}{*}{ Medium (1650-1750) } & Cage $_{1}$ & Cage $_{1}$ & Cage $_{1}$ & Cage $_{1}$ \\
\hline & Cage $_{2}$ & $\mathrm{Cage}_{2}$ & $\mathrm{Cage}_{2}$ & Cage $_{2}$ \\
\hline & $\mathrm{Cage}_{3}$ & $\mathrm{Cage}_{3}$ & $\mathrm{Cage}_{3}$ & $\mathrm{Cage}_{3}$ \\
\hline \multirow{3}{*}{ Low $(<1650)$} & Cage $_{1}$ & Cage $_{1}$ & & \\
\hline & Cage $_{2}$ & Cage $_{2}$ & & \\
\hline & Cage $_{3}$ & $\mathrm{Cage}_{3}$ & & \\
\hline
\end{tabular}

m. a. s. $l=$ Meters above sea level 
Table 2. The relationship between rainfall and dry matter yield $\left(\mathrm{g} / 1.2 \mathrm{~m}^{2} / 30 \mathrm{~d}\right)$ of the forages in the open and closed areas of Umbulo Wacho watershed.

\begin{tabular}{|c|c|c|c|c|c|c|}
\hline \multirow[b]{2}{*}{$\begin{array}{l}\text { Sampling } \\
\text { time }\end{array}$} & \multirow[b]{2}{*}{$\begin{array}{c}\text { Rainfall } \\
\text { (mm/month) }\end{array}$} & \multicolumn{4}{|c|}{ DMY in the open and closed areas } & \multirow[b]{2}{*}{ Mean } \\
\hline & & Open & $\begin{array}{c}\text { Closed for } 2 \\
\text { years }\end{array}$ & $\begin{array}{c}\text { Closed for } 3 \\
\text { years }\end{array}$ & $\begin{array}{c}\text { Closed for } 4 \\
\text { years }\end{array}$ & \\
\hline May & 150 & 237 & 144 & 80 & 65 & 144 \\
\hline June & 45 & 111 & 84 & 28 & 43 & 81 \\
\hline July-Sept. & 104 & 86 & 41 & 33 & 26 & 53 \\
\hline \multirow[t]{2}{*}{ Oct.-Nov. } & 42 & 42 & 30 & 14 & 9 & 29 \\
\hline & Mean & 121 & 75 & 57 & 54 & \\
\hline
\end{tabular}

$D M Y=$ Dry matter yield

\subsection{In-Vitro Dry Matter Digestibility}

The in-vitro dry matter digestibility (IVDMD) was determined by the method of Tilley and Terry (1963) as modified by Van Soest and Robertson (1985).

\subsection{Statistical Analyses}

The GLM procedure of SAS (1998) was employed for the ANOVA of DM, DMY, CP, NDF, ADF, ADL, Ca, $\mathrm{P}$, total ash and IVDMD in a randomized complete block design (RCBD) where the altitudinal zones were blocked into open and closed areas. The three factors were condition of the area (closed or open), sampling time and altitude of the area. Means were considered to be significant at $\mathrm{P}<0.05$. When least square means (LS means) of nutrient contents, DMY and IVDMD were significant, they were separated by least significant difference (LSD). Partial correlation procedures were used to determine the relationship between nutrients, IVDMD, condition of the area (open or closed), sampling time and altitude. The effects of the condition of the area (open or closed), sampling time and altitude on parameters considered were determined using the following model:

$$
\mathrm{Y}_{\mathrm{ijlk}}=\mu+\mathrm{A}_{\mathrm{i}}+\mathrm{B}_{\mathrm{j}}+\mathrm{C}_{\mathrm{l}}+\mathrm{AB}_{\mathrm{ij}}+\mathrm{BC}_{\mathrm{jl}}+\mathrm{AC}_{\mathrm{il}}+\varepsilon_{\mathrm{ijlk}}
$$

where $\mathrm{Y}_{\mathrm{ijlk}}=$ biomass production and nutritive value (nutrient contents, DMY, IVDMD); $\mu$ = overall mean; $A_{i}$ $=$ effect of condition of the area (closed or open); $B_{j}=$ effect of sampling time (months); $C_{1}=$ effect of altitude (slopes); $\mathrm{AB}_{\mathrm{ij}}=$ interaction effect of condition of the area and sampling time; $\mathrm{BC}_{\mathrm{jl}}=$ interaction effect of sampling time and altitude; $\mathrm{AC}_{\mathrm{il}}=$ interaction effect of condition of the area and altitude; $\varepsilon_{\mathrm{ijlk}}=$ random error

Multiple regression analysis was conducted for the dependent variables (DM yield, nutrient content and IVDMD) and independent variables (condition of the area, sampling time and altitude) using the following model:

$\mathrm{Y}=\beta_{0}+\beta_{1}$ (condition of area) $+\beta_{2}$ (sampling time) $+\beta_{3}$ (altitude) $+\varepsilon_{\mathrm{ijkl}}$ where: $\mathrm{Y}_{\mathrm{ijkl}}=$ biomass production and nutritive value (nutrient contents, DMY, IVDMD); $\beta_{0}=$ constant (intercept); $\beta_{1}, \beta_{2}, \beta_{3}=$ regression coefficients (slopes of the independent variables); $\varepsilon_{\mathrm{ijkl}}=$ random error

\section{Results and Discussion}

\subsection{Forage Biomass Production}

When the study was planned, it was assumed that there would be a continuous occurrence of grasses, legumes and other species during the entire experimental period. However, with the exception of the first sampling time (May), it was actually found that, except in some of the cages, there was no re-growth of legumes or other species other than grasses, possibly due to poor recovery of the species. Perennial bunch type grasses formed the main part of the re-growth at each cutting in both closed and open areas.

\subsubsection{Dry Matter Content and Yield}

The DM content of the grasses was $30.80 \pm 2.97 \%$ with a minimum of $24.1 \%$ and a maximum of $42.6 \%$. The $\mathrm{DM}$ content of grasses re-grown was significantly influenced $(\mathrm{P}<0.01)$ by sampling time, altitude and by the interactions between condition of the area, sampling time and altitude (Table 2). The lowest DM content was recorded at the bottom of the watershed, but there was no significant difference $(\mathrm{P}>0.05)$ in the mean forage DM content between the high and medium altitudes (Table 5). The interaction effect between altitude and age of closed areas; and between condition of the area and sampling time on the DM content were significant $(\mathrm{P}<$ $0.01)$.

The differences in mean DM content of the re-growth of grasses during May, June and October-November were not significant $(\mathrm{P}>0.05)$, but $\mathrm{DM}$ content was significantly lower $(\mathrm{P}<0.05)$ during July-September compared to the above means (Table 3 ). 
Table 3. The nutrient contents, dry matter yield and in-vitro dry matter digestibility of the natural pasture harvested at various periods in Umbulo Wacho watershed harvested over four sampling periods.

\begin{tabular}{|c|c|c|c|c|}
\hline \multirow{3}{*}{ Parameter } & \multicolumn{4}{|c|}{ Sampling period } \\
\hline & May & June & July-September & October-November \\
\hline & Mean $\pm \mathrm{SE}$ & Mean $\pm \mathrm{SE}$ & Mean \pm SE & Mean \pm SE \\
\hline & \multicolumn{4}{|c|}{ Nutrient content } \\
\hline$\overline{\text { Dry matter }(\%)}$ & $31.56^{\mathrm{a}} \pm 0.57$ & $30.85^{\mathrm{a}} \pm 0.57$ & $27.78^{\mathrm{b}} \pm 0.56$ & $30.55^{a} \pm 0.56$ \\
\hline $\mathrm{OM}(\% \mathrm{DM})$ & $83.02^{\mathrm{b}} \pm 0.53$ & $84.67^{a} \pm 0.53$ & $83.49^{\mathrm{ab}} \pm 0.52$ & $83.32^{\mathrm{ab}} \pm 0.52$ \\
\hline Crude protein (\% DM) & $13.68^{a} \pm 0.42$ & $13.06^{\mathrm{ab}} \pm 0.42$ & $12.65^{\mathrm{abc}} \pm 0.42$ & $11.66^{c} \pm 0.42$ \\
\hline Total ash (\% DM) & $16.98^{a} \pm 0.53$ & $15.32^{\mathrm{b}} \pm 0.53$ & $16.53^{\mathrm{ab}} \pm 0.52$ & $16.68^{\mathrm{ab}} \pm 0.52$ \\
\hline Phosphorus (\% DM) & $0.39^{a} \pm 0.02$ & $0.29^{\mathrm{b}} \pm 0.02$ & $0.29^{\mathrm{b}} \pm 0.02$ & $0.22^{\mathrm{c}} \pm 0.02$ \\
\hline Calcium (\% DM) & $0.65^{a} \pm 0.02$ & $0.65^{\mathrm{a}} \pm 0.0 .02$ & $0.62^{a} \pm 0.02$ & $0.64^{a} \pm 0.02$ \\
\hline $\mathrm{ADF}(\% \mathrm{DM})$ & $34.67 \mathrm{a} \pm 0.50$ & $31.83^{\mathrm{b}} \pm 0.50$ & $32.39 \mathrm{ab} \pm 0.49$ & $31.21^{b} \pm 0.49$ \\
\hline $\mathrm{ADF}$ ash $(\% \mathrm{DM})$ & $7.87^{\mathrm{ab}} \pm 0.41$ & $6.82^{b} \pm 0.41$ & $8.08^{a} \pm 0.40$ & $7.78^{\mathrm{ab}} \pm 0.40$ \\
\hline $\mathrm{ADL}(\% \mathrm{DM})$ & $4.85^{\mathrm{b}} \pm 0.22$ & $3.94^{a} \pm 0.22$ & $4.71^{b} \pm 0.22$ & $4.52^{\mathrm{ab}} \pm 0.22$ \\
\hline \multirow[t]{2}{*}{ NDF $(\% \mathrm{DM})$} & $66.74^{a} \pm 0.81$ & $66.69^{a} \pm 0.81$ & $66.94^{a} \pm 0.79$ & $66.89^{a} \pm 0.79$ \\
\hline & \multicolumn{4}{|c|}{ Dry matter yield and digestibility } \\
\hline$\overline{\mathrm{DMY}\left(\mathrm{g} / 1.21 \mathrm{~m}^{2} / 30 \mathrm{~d}\right)}$ & $143.13^{a} \pm 8.94$ & $76.62^{\mathrm{b}} \pm 8.94$ & $52.59^{\mathrm{c}} \pm 8.74$ & $29.28^{\mathrm{d}} \pm 8.74$ \\
\hline IVDMD $(\%)$ & $71.51^{\mathrm{a}} \pm 1.12$ & $71.91^{\mathrm{a}} \pm 1.12$ & $73.99^{\mathrm{a}} \pm 1.09$ & $71.23^{a} \pm 1.09$ \\
\hline
\end{tabular}

The DMY was $71.34 \pm 46.40 \mathrm{~g} / 1.21 \mathrm{~m}^{2} / 30$ days or 0.59 \pm 0.06 tones $/$ ha/30 days. The highest DMY was obtained at the bottom of the watershed and the lowest at high altitude which is sloppy and degraded (Table 5). Because of the sloppy topography, the topsoil from the medium altitude was washed to the bottom of the watershed which, most probably, improved soil fertility and contributed to the increased DMY in the open area at the bottom of the watershed. According to Senbeto (2006), the watershed had a total of 117.1 ha of natural pasture and 4431 TLU; and thus it provides 829.07 tones of $\mathrm{DM} /$ year $(0.59 * 117.1 * 12)$ which is able to meet only about $8.20 \%$ of the total annual DM requirement (2281 $\mathrm{kg} \mathrm{DM} / \mathrm{TLU} /$ year x $4431=10,107.11$ tones) according to the formula of Jahnke (1982)

The highest $(\mathrm{P}<0.05)$ DMY was recorded from the open area and the lowest from the area closed for 4 years, although not significantly different $(\mathrm{P}>0.05)$ from the DMY obtained from the area closed for 2 and 3 years (Table 4). The higher DMY in the open areas could be attributed to inputs of manure from grazing animals. Organic fertilizers, feces and urine were not added to those areas which were closed for a longer period of time and therefore, this could be a possible reason for reduced DMY. Grasses that have stayed there for a long time might have exhaustively used the available nutrients and depleted the soil and could have influenced the re-growth rate and reduced DMY. The speed and extent of nutrients recycling as a result of OM decomposition were probably not able to compensate the depletion. There was a significant reduction $(\mathrm{P}<0.05)$ in DMY of regrowth of forages with increasing age of the closed areas.

The lowest DMY in most cases was recorded from high altitudes which were closed over three years (Table $5)$. The interaction between the age of the closed area and sampling time on DMY was significant $(\mathrm{P}<0.05)$ and there was a decreasing trend of DMY towards the beginning of the dry season (Table 6 and 7). The highest DMY was recorded in May which received the highest amount of rainfall in the study period (Table 2). The amounts of rainfall in June and between October and November are almost similar, but the DMY during June was much higher than between October and November. The amount of rainfall in the period between July and September was much higher than in June but the DMY between July and September was even much smaller than in June (Table 3), which is hard to explain from the rainfall data alone.

The lower range of DMY in this study, compared to the report by Wilkins (2000), might be due to the short cutting interval of the forages, soil degradation and poor vegetation cover. Some of the areas selected were productive and in use for grazing; others were closed for shorter (2 years), medium (3 year) and longer periods (4 years). The difference in the level of succession at different altitudes and age of closure might have contributed to the reduction in the mean DMY of grasses in the watershed. The condition of the area, sampling time, altitude and their interactions had significant $(\mathrm{P}<$ 0.01) effects on DMY.

\subsubsection{Nutrient Content}

The CP content of the grasses was $12.73 \pm 2.20 \% \mathrm{DM}$, ranging between $7.82 \%$ and $21 \%$. Soni (1975) indicated that grasses in the tropics have values approaching a constant CP content of $12 \%$. Moreover, the mean CP content of Rhodes grasses was reported by Daniel (1988) to be $13.3 \% \mathrm{DM}$ without nitrogen fertilization at $100 \%$ leaf stage which is slightly higher than the overall mean CP content obtained in this study.

Crude protein content was significantly $(\mathrm{P}<0.01)$ influenced by sampling time, the existing condition of the area (open vs. closed) and altitude. 
Table 4. The nutrient contents, dry matter yield and in-vitro dry matter digestibility of the natural pasture from closed and open areas of Umbulo Wacho watershed.

\begin{tabular}{|c|c|c|c|c|}
\hline \multirow{3}{*}{ Parameter } & \multicolumn{4}{|c|}{ Conditions of the area } \\
\hline & Open & Closed (2 years) & Closed (3 years) & Closed (4 years) \\
\hline & Mean $\pm \mathrm{SE}$ & Mean $\pm \mathrm{SE}$ & Mean $\pm \mathrm{SE}$ & Mean $\pm \mathrm{SE}$ \\
\hline & \multicolumn{4}{|c|}{ Nutrient content } \\
\hline Dry matter $(\%)$ & $29.95^{\mathrm{a}} \pm 0.50$ & $30.92^{a} \pm 0.51$ & $30.45^{a} \pm 0.66$ & $29.41^{a} \pm 0.66$ \\
\hline $\mathrm{OM}(\% \mathrm{DM})$ & $85.15^{\mathrm{a}} \pm 0.46$ & $83.37^{b} \pm 0.47$ & $83.07^{b} \pm 0.61$ & $82.92^{\mathrm{b}} \pm 0.61$ \\
\hline Crude protein $(\% \mathrm{DM})$ & $15.99^{\mathrm{a}} \pm 0.37$ & $11.98^{\mathrm{b}} \pm 0.38$ & $11.83^{\mathrm{b}} \pm 0.49$ & $11.25^{\mathrm{b}} \pm 0.49$ \\
\hline Total ash (\% DM) & $14.87^{b} \pm 0.46$ & $16.63^{a} \pm 0.47$ & $16.93^{a} \pm 0.61$ & $17.08^{a} \pm 0.61$ \\
\hline Phosphorus (\% DM) & $0.48^{a} \pm 0.02$ & $0.27 \mathrm{~b} \pm 0.02$ & $0.23^{b c} \pm 0.02$ & $0.20^{c} \pm 0.02$ \\
\hline Calcium (\% DM) & $0.69 \mathrm{a} \pm 0.02$ & $0.62^{\mathrm{b}} \pm 0.02$ & $0.61^{b} \pm 0.03$ & $0.64^{\mathrm{ab}} \pm 0.03$ \\
\hline $\mathrm{ADF}(\% \mathrm{DM})$ & $29.94^{b} \pm 0.43$ & $33.20^{\mathrm{a}} \pm 0.44$ & $33.30^{\mathrm{a}} \pm 0.57$ & $33.64^{a} \pm 0.57$ \\
\hline $\mathrm{ADF}$ ash (\% DM) & $5.74^{b} \pm 0.35$ & $7.86^{a} \pm 0.36$ & $8.15^{a} \pm 0.47$ & $8.81^{\mathrm{a}} \pm 0.47$ \\
\hline $\mathrm{ADL}(\% \mathrm{DM})$ & $4.61^{a} \pm 0.19$ & $4.45^{a} \pm 0 . .20$ & $4.55^{a} \pm 0.25$ & $4.42^{a} \pm 0.25$ \\
\hline \multirow[t]{2}{*}{ NDF (\% DM) } & $67.34^{\mathrm{a}} \pm 0.70$ & $66.36^{a} \pm 0.72$ & $67.37^{a} \pm 0.93$ & $66.20^{a} \pm 0.93$ \\
\hline & \multicolumn{4}{|c|}{ Dry matter yield and digestibility } \\
\hline DMY (g/1.21 m²/30 d) & $119.08^{a} \pm 7.73$ & $73.02^{\mathrm{b}} \pm 7.98$ & $56.15^{\mathrm{b}} \pm 10.28$ & $53.38^{\mathrm{b}} \pm 10.28$ \\
\hline $\operatorname{IVDMD}(\%)$ & $74.52^{\mathrm{a}} \pm 0.97$ & $71.39 \mathrm{~b} \pm 1.00$ & $71.47^{\mathrm{ab}} \pm 1.28$ & $71.26^{\mathrm{b}} \pm 1.28$ \\
\hline
\end{tabular}

Table 5. The nutrient contents, dry matter yield and in-vitro dry matter digestibility of the natural pasture at three altitudinal zones of Umbulo Wacho watershed.

\begin{tabular}{|c|c|c|c|}
\hline \multirow{3}{*}{ Parameter } & \multicolumn{3}{|c|}{ Altitude } \\
\hline & High & Medium & Low \\
\hline & Mean $\pm \mathrm{SE}$ & Mean $\pm \mathrm{SE}$ & Mean $\pm \mathrm{SE}$ \\
\hline & \multicolumn{3}{|c|}{ Nutrient content } \\
\hline Dry matter $(\%)$ & $31.60^{\mathrm{a}} \pm 0.43$ & $31.46^{a} \pm 0.43$ & $27.49^{\mathrm{b}} \pm 0.70$ \\
\hline $\mathrm{OM}(\% \mathrm{DM})$ & $83.70^{\mathrm{a}} \pm 0.40$ & $83.98^{a} \pm 0.40$ & $83.19^{a} \pm 0.65$ \\
\hline Crude protein $(\% \mathrm{DM})$ & $12.65^{\mathrm{b}} \pm 0.32$ & $11.57^{c} \pm 0.32$ & $14.07^{\mathrm{a}} \pm 0.52$ \\
\hline Total ash $(\% \mathrm{DM})$ & $16.30^{\mathrm{a}} \pm 0.40$ & $16.02^{a} \pm 0.40$ & $16.81^{\mathrm{a}} \pm 0.65$ \\
\hline Phosphorus (\% DM) & $0.23^{\mathrm{b}} \pm 0.01$ & $0.20^{\mathrm{b}} \pm 0.01$ & $0.46^{\mathrm{a}} \pm 0.02$ \\
\hline Calcium (\% DM) & $0.64^{a} \pm 0.02$ & $0.64^{\mathrm{a}} \pm 0.02$ & $0.64^{a} \pm 0.03$ \\
\hline $\mathrm{ADF}(\% \mathrm{DM})$ & $32.14^{\mathrm{b}} \pm 0.37$ & $33.99 a \pm 0.37$ & $31.43^{\mathrm{b}} \pm 0.61$ \\
\hline $\mathrm{ADF}$ ash $(\% \mathrm{DM})$ & $8.05^{\mathrm{a}} \pm 0.31$ & $8.01^{\mathrm{a}} \pm 0.31$ & $6.85^{b} \pm 0.50$ \\
\hline $\mathrm{ADL}(\% \mathrm{DM})$ & $4.49^{a} \pm 0.16$ & $4.52^{a} \pm 0.16$ & $4.51^{\mathrm{a}} \pm 0.27$ \\
\hline \multirow[t]{2}{*}{ NDF (\% DM) } & $65.54^{\mathrm{b}} \pm 0.61$ & $67.29^{a} \pm 0.61$ & $67.62^{\mathrm{a}} \pm 1.00$ \\
\hline & \multicolumn{3}{|c|}{ Dry matter yield and digestibility } \\
\hline $\operatorname{DMY}\left(\mathrm{g} / 1.21 \mathrm{~m}^{2} / 30 \mathrm{~d}\right)$ & $50.14^{\mathrm{b}} \pm 6.70$ & $65.61^{\mathrm{b}} \pm 6.70$ & $110.46^{a} \pm 10.99$ \\
\hline $\operatorname{IVDMD}(\%)$ & $72.85^{\mathrm{a}} \pm 0.84$ & $70.35^{\mathrm{b}} \pm 0.84$ & $73.28^{a} \pm 1.37$ \\
\hline
\end{tabular}

The highest CP content of the grasses was recorded in May and was significantly different $(\mathrm{P}<0.05)$ from that of the last cutting period (Table 3). The reduction of the mean CP content with advance into the dry season might be due to the accumulation of structural carbohydrates and the rapid rate of maturity caused by high environmental temperature and low rainfall.

The highest $(\mathrm{P}<0.05) \mathrm{CP}$ content compared to all closed areas was recorded from the open area which might have increased due to the fertilizing effect of livestock manure (Table 4). The lowest CP content, although not significantly different $(\mathrm{P}>0.05)$, was recorded in the area closed for 4 years which indicates that the CP content significantly decreased with increasing age of closure. According to Sarawa et al. (1999), the CP content varied widely among forage plants and it declined with increasing age of forages. Crude protein content of Napier grass showed an increasing trend with reduced days of harvesting (Hassan et al., 1990).

The CP content of the grasses was significantly influenced by the altitude and slope of the watershed. The highest $\mathrm{CP}$ content $(\mathrm{P}<0.05)$ was recorded from the bottom of the watershed rather than at the top (Table 5 ), possibly due to continuous supply of nitrogen through excreta of grazing animals. It was also observed that the $\mathrm{CP}$ content of the grasses decreased with 
increasing slope of the area which is prominent at medium altitude.

The ash content of the grasses was $16.15 \pm 2.75 \% \mathrm{DM}$ with a minimum of $11.2 \%$ and maximum of $28.6 \%$. The lowest $(\mathrm{P}<0.05)$ ash content was recorded for the grasses on the open area (Table 3). The ash content of the grasses from all the closed areas was greater than those on the open areas. It tended to increase with increasing age of the closed areas. This agrees with the reports of Hassan et al. (1990) that the ash content of grasses significantly declined as days of harvesting increased from 2 to 8 weeks; and with that of Underwood (1981) which showed that mineral fraction in forages declined significantly with maturity, but the rate and extent of the decline varied with time of the year and seasonal condition.

A general decreasing trend in ash content was observed with increasing DMY. According to Berihun (2005), the increase in ash content with decreasing DMY might be due to natural dilution and translocation of nutrients during growth and development of plant tissues.

Total ash content was significantly affected $(\mathrm{P}<0.05)$ only by the interaction between the condition of the area with altitude (Table 7), for the simple reason that it was highly affected by the condition of the area. There was no significant interaction effect $(\mathrm{P}>0.05)$ of sampling time and altitude and all other possible interactions on total ash content.

The $\mathrm{P}$ content of the grasses was $0.28 \pm 0.10 \% \mathrm{DM}$ ranging from 0.05 to $0.9 \%$. The range of $\mathrm{P}$ content of grasses found in this study is in agreement with the range of values (0.1 to $0.6 \%$ ) reported for $\mathrm{P}$ in tropical grasses or legumes (Whitehead, 2000). Conditions of the area, sampling time and altitude and the interaction effect (Table 7) between these factors on the $\mathrm{P}$ content of grasses were significant $(\mathrm{P}<0.01)$.

The highest $\mathrm{P}$ content $(\mathrm{P}<0.05)$ was recorded from May cutting at the time when highest DMY was recorded, but the lowest from October to November cutting when the lowest DMY was obtained (Table 3). According to Whitehead (2000), a decrease in P content with advance in the dry season could possibly and partly be justified by the fact that the concentration of $\mathrm{P}$ in grasses decreases with increasing temperature. Kabaija and Smith (1988) conducted a study on the effect of season on $\mathrm{P}$ yields in Panicum maximum and Cynodon nlemfuensis (Chedda) during early wet season, late wet season and late dry season and obtained 55.5, 15.3, 10.4 $\mathrm{g} / \mathrm{kg}$, respectively, which had a similar decreasing trend as observed in this study.

The lowest P content of grasses was recorded from the open area and the highest from the area closed for 4 years (Table 4). The study indicated that there was a decreasing trend of $\mathrm{P}$ content with increasing age of the closed area. The significant reduction in the $\mathrm{P}$ content of grasses from areas closed for a longer period might be due to lack of $\mathrm{P}$ fertilization from excreta as the area was not grazed by animals. Similar justification has also been reported by Wilkins (2000).
The average $\mathrm{Ca}$ content of the grasses was $0.64 \pm$ $0.12 \%$ DM ranging from 0.31 to $1.1 \%$. Minson (1990) reported the $\mathrm{Ca}$ content of 390 samples of tropical grasses grown throughout the world to vary from 0.14 to $1.46 \%$ DM with a mean of $0.4 \%$. Whitehead (2000) also found that the concentration of $\mathrm{Ca}$ in herbages ranged between 0.1 to $2.6 \%$, and that the highest values were for the legumes rather than the grass species. Relatively high Ca content in this study could be due to the cutting of grasses at short intervals and at an early stage of regrowth. The concentration of $\mathrm{Ca}$ found in this study is sufficient to meet the requirements for cattle which agree with the reports of Minson (1990) that showed $0.17 \% \mathrm{Ca}$ in the DM of the diet can meet the requirement of cattle weighing $450 \mathrm{~kg}$ and gaining $0.5 \mathrm{~kg} / \mathrm{day}$. Thus, this study showed that grazing animals could get the required amount of calcium if the grasses are used at an early stage of growth, provided the animals get the required amount of forage DM.

Although not significantly different $(\mathrm{P}>0.05)$, higher Ca contents were recorded in forages harvested in May and June (Table 3) when high DMY was recorded. The work of Whitehead (2000) indicated that relatively high concentration of $\mathrm{Ca}$ sometimes occurs during periods of active growing which agrees with the finding of this study. Although differences in $\mathrm{Ca}$ content between duration of closure (Table 4) were not significant, the highest $\mathrm{Ca}$ content was recorded in the area closed for 4 years. As shown in Table 7, the effect of two-way interactions between the condition of the area, sampling time and altitude on the $\mathrm{Ca}$ content of grasses were all significant $(\mathrm{P}<0.01)$.

The average NDF content of the grasses was $66.66 \pm$ 4.21\% DM, which ranged between $41.3 \%$ and $75.6 \%$. Barton (1997) found similar percentages of NDF in tropical grasses cut at 4 weeks interval. The similarity in the NDF content might be related to the similar cutting interval of the grasses in the two studies without considering other environmental factors. The NDF content of Pennisetum purpureum $\times$ Pennisetum americium cut at 60 days interval in Ethiopia in a properly managed condition was between 59 and 61\% (Berihun, 2005), the minimum NDF content (59\%) is $18 \%$ higher than the minimum NDF content obtained in this study, which shows that the NDF content can be reduced by harvesting grasses earlier than at 60 days of stage of growth.

Differences in NDF content of grasses between sampling times (Table 3) and conditions of the area (Table 4) were not significant $(\mathrm{P}>0.05)$. However, Adane (2003) reported increasing trends of NDF content with extended days of harvesting. Grasses from high altitude had significantly lower NDF content than those from medium and low altitudes (Table 5). There is no significant $(\mathrm{P}>0.05)$ interaction effect of sampling time, altitude and conditions of the area on the NDF content of grasses (Table 6). 
Table 6. The regression coefficients of nutrient content of grasses as dependent on condition of the area (closed/open), sampling time and altitude.

\begin{tabular}{|c|c|c|c|c|}
\hline Variable & Condition of the area $(\beta 1)$ & Sampling time ( $\beta 2)$ & Altitude $(\beta 3)$ & Intercept $(\beta 0)$ \\
\hline DM & $0.04^{\mathrm{ns}}$ & $-0.6^{*}$ & $-1.7 * *$ & $35.1^{* *}$ \\
\hline DMY & $-23.9 * *$ & $-36.3^{* *}$ & $26.7 * *$ & $170^{* *}$ \\
\hline $\mathrm{CP}$ & $-1.7^{* *}$ & $-0.6^{* *}$ & $0.3^{\text {ns }}$ & $17.9 * *$ \\
\hline ADF & $1.4^{* *}$ & $-0.98 * *$ & $0.2^{\mathrm{ns}}$ & $31.4^{\mathrm{ns}}$ \\
\hline NDF & $-0.2^{\text {ns }}$ & $0.1^{\mathrm{ns}}$ & $1.1 *$ & $64.9^{\mathrm{ns}}$ \\
\hline ADL & $-0.05^{\text {ns }}$ & $-0.02^{\mathrm{ns}}$ & $0.01^{\mathrm{ns}}$ & $4.7^{\mathrm{ns}}$ \\
\hline Ash & $0.6^{*}$ & $-0.2^{*}$ & $-0.2^{\mathrm{ns}}$ & $15.4 * *$ \\
\hline $\mathrm{P}$ & $-0.1^{* *}$ & $-0.1 * *$ & $0.07 * *$ & $0.5^{* *}$ \\
\hline $\mathrm{Ca}$ & $-0.02^{\text {ns }}$ & $-0.01^{\mathrm{ns}}$ & $0.02^{\mathrm{ns}}$ & $0.7 * *$ \\
\hline IVDMD & $-1.5^{* *}$ & $1.2^{\mathrm{ns}}$ & $-0.2^{\mathrm{ns}}$ & $73.8^{* *}$ \\
\hline
\end{tabular}

The ADF content of grasses was $32.55 \pm 2.58 \% \mathrm{DM}$ ranging between $23.0 \%$ and $41.5 \%$. The $\mathrm{ADF}$ content of tropical grasses cut at 4 weeks interval was found to be 35.2\% (Barton, 1997). According to Ghadaki et al. (1975), ADF content of tropical grasses at an early stage of growth was $25.9 \%$, which is slightly lower than the result obtained in this study.

ADF content of grasses was significantly and positively influenced $(\mathrm{P}<0.01)$ by the condition of the area, sampling time and altitude; and by the interaction between the condition of the area and sampling time ( $\mathrm{P}$ $<0.05)$; and between altitude and the condition of the area $(\mathrm{P}<0.01)$ (Table 7$)$.

Mean ADF content was highest $(\mathrm{P}<0.05)$ in May cutting. The lowest ADF content was recorded from cuttings between October and November, but was not significantly different $(\mathrm{P}>0.05)$ from those of June and July - September (Table 3).

Significantly the highest ADF value was obtained in medium altitude (Table 5) where the grasses might have matured rapidly and accumulated higher structural carbohydrates such as cellulose and lignin as a mechanism of adaptation to low moisture and infertile soil.

Mean ADF content of grasses from the open area was lower than those of the closed areas (Table 4). The shortage of nutrients in the closed area might have led grasses to mature rapidly, as a result of which the ADF content increased. Similar results were reported where $\mathrm{ADF}$ contents from $20 \%$ to over $45 \%$ in very mature species of grasses (McDonald et al., 2002) and an increasing trend in $\mathrm{ADF}$ content (from $22.4 \%$ to $42.9 \%$ ) was observed with advanced age (from 30 and 120 days, respectively) of plants (Adane, 2003). It has been found that, with increasing age of closure, the nutritional quality of grasses decreased because of an increasing trend of ADF content even if the grass samples were cut at the same interval.

The average ADL content of grasses was $4.51 \pm 1.14 \%$ DM ranging between $2.6 \%$ to $10.7 \%$. Similar results were reported by Barton (1997) where tropical grasses at 4 weeks cutting interval had an average ADL content of $4.9 \%$.

The lowest ADL content was recorded in June (Table 3). Lack of significant difference in ADL at most of the sampling times might be related to short cutting intervals where grasses were cut young and there was less lignification. It was indicated by Whiteman (1980), that lignification of forages occurs almost constantly with increasing stage of growth. It was also reported that tropical grasses are characterized by low nutritive value due to high lignin content and fewer degradable materials in their cell wall caused by rapid rate of maturity (Minson, 1990). Increasing trends of ADL contents were also recorded with advanced harvesting ( $\mathrm{McD}$ onald et al., 2002).

ADL content was significantly influenced $(\mathrm{P}<0.01)$ by sampling time and by the interaction between condition of the area and altitude, and between sampling time and altitude (Table 7). Differences in ADL content of the grasses from the open and closed areas (Table 4) as well as from different altitudes (Table 5) were not significant $(\mathrm{P}>0.05)$.

\subsubsection{In-Vitro Dry Matter Digestibility}

The overall IVDMD was $72.10 \pm 5.80 \%$ ranging between 49.45 and $82.8 \%$. The mean IVDMD of tropical grasses cut at 4-weeks interval was 57.8\% (Barton, 1997), which is much lower than the result obtained in this study.

The grasses from the open area had significantly higher $(\mathrm{P}<0.01)$ IVDMD than from the closed areas (Table 4). The lowest $(\mathrm{P}<0.05)$ IVDMD was recorded in forages harvested from medium altitude than from low and high altitudes (Table 5). This could be related to the lower amounts of ADF and NDF in grasses from the low and high altitudes and the vice versa in grasses from the medium altitude. The higher mean IVDMD was recorded in the open area because of lower ADF and ash content.

The following reports indirectly agree with the results of this experiment because they are related to variation in fiber fractions of the forages. McDonald et al. (2002) expressed that forage digestibility decreases rapidly with 
advancing maturity and low leaf to stem ratio. Hassan et al. (1990) also showed that IVDMD decreased as the cutting interval increased from 2 to 8 weeks in tropical grasses and intermediate values were recorded at 4 to 6 weeks intervals.

\subsection{Biomass Production of Legumes and Species Other Than Grasses}

In the current watershed, there is no promising amount of legumes and other species other than grasses recorded. Bunch type perennial grasses are dominant in the area. A few species of forages other than grasses were observed in the cages mainly during first cutting (May). The percentage occurrence of legumes and species other than grasses in all the 30 sampling sites over 7 months were only $6.6 \%$ and $10 \%$, respectively, with a combined DM, $\mathrm{CP}$ and $\mathrm{P}$ contents of $14.4,17.3$ and $0.74 \%$, respectively. Even if the CP and P contents of the legume species were high, their CP and P contribution to livestock in the area was insignificant, because of their low proportions and uneven distribution in the watershed.

The reduction or complete extinction of legumes and species other than grasses after the first sampling period might be due to low level of rainfall for optimum regrowth, short cutting interval, poor condition of the soil, and their weak level of competition with permanently rooted bunch type grasses (Njunie et al., 1993).

Table 7. Analysis of variance of the influence of sampling time, altitude, area closure; and their interaction on nutrient content (mean squares).

\begin{tabular}{|c|c|c|c|c|c|c|}
\hline & Sampling time (ST) & Altitude (Alt) & Area closure (AC) & ST*ALT & ST*AC & Alt *AC \\
\hline DMY (gm) & $65263^{* *}$ & $29198^{* *}$ & $23492^{* *}$ & $8325^{* *}$ & $5542^{* *}$ & $14215^{* *}$ \\
\hline DM $(\%)$ & $76^{* *}$ & $118^{* *}$ & 12 & 7 & $23 * *$ & $48^{* *}$ \\
\hline Ash (\%) & 10 & 4 & $31 * *$ & 13 & 8 & $19 *$ \\
\hline $\mathrm{CP}(\%)$ & $23^{* *}$ & $47^{* *}$ & $136^{* *}$ & 3 & 4 & $16^{* *}$ \\
\hline ADF $(\%)$ & $75^{* *}$ & $58^{* *}$ & $92^{* *}$ & 6 & $11 *$ & $24 * *$ \\
\hline NDF $(\%)$ & 4 & 64 & 4 & 21 & 19 & 15 \\
\hline ADL (\%) & $3.55^{* *}$ & 0.14 & 0.11 & $2.46^{* *}$ & 0.95 & $5.59 * *$ \\
\hline IVDMD (\%) & 64 & 63 & $71 *$ & 41 & 7 & $176^{* *}$ \\
\hline $\mathrm{Ca}(\%)$ & 0.005 & 0.001 & $0.033^{* *}$ & $0.024 * *$ & $0.023 * *$ & $0.078^{* *}$ \\
\hline $\mathrm{P}(\%)$ & $0.13^{* *}$ & $0.05^{* *}$ & $0.46^{* *}$ & $0.01 * *$ & $0.03 * *$ & $0.07 * *$ \\
\hline
\end{tabular}

\section{Conclusions}

The longer an area is closed, the smaller the DMY and the lower the CP, P and IVDMD, and the higher ash and ADF contents of re-growth. For feeding to livestock forages should cut as frequently as possible when nutrient contents are optimum. With advance in sampling time from the rainy to the dry season, percentages of DM, CP, ADF, ash, $\mathrm{P}$ and $\mathrm{DMY}$ decreased. With increasing altitude DMY, NDF and P contents increased, but DM content reduced.

Further study on identification of species composition of forages in the closed and open areas; effects of legume over-sowing on forage biomass productivity and species composition of the natural pasture; and forage biomass production study over several seasons and different cutting ages are suggested.

\section{Acknowledgments}

We gratefully acknowledge the Irish Aid Operational Research of Hawassa University for funding this study as well as its coordinator Mr. Tewodros Tefera for facilitating the study. Our thanks also go to the respective staff members of Boricha and Hawassa Zuria Woreda and also Assistants of Animal Nutrition Laboratory of Hawassa University for their valuable supports and to Mr. Behailu Tefera of Metal Workshop of Agricultural
Engineering and Mechanization Department for preparing the exclusion cages.

\section{References}

Abule, E. 2003. Rangeland evaluation in relation to pastoralist's perception in the Mid-Awash rift valley of Ethiopia. Ph.D. Dissertation, University of Free State, Bloemfontein, South Africa.

Adane, K. 2003. Effect of stage of growth and fertilizer application on dry matter yield and quality of natural grassland in highland of North Shoa, Oromia Region, M.Sc thesis, Alemaya University, Ethiopia.

Admasu, T. 2006. Pastoralist's perceptions on rangelivestock management practices and rangeland assessment in Hamer and Benna-Tsemay district of South Omo Zone. M.Sc. Thesis, Alemaya University, Ethiopia.

Adugna, T. 1990. Animal production and feed resource constraints in Welayita Sodo and the supplementary value of Desmodium intortum, Stylosanthes guianenisis and Macratyloma axillare when fed to growing sheep feeding on a basal diet of maize stover, M.Sc. Thesis, Agricultural University of Norway, Norway.

Ahmed, B. 2003. Soil condition and vegetation cover in human impacted rangelands of Jijiga, Somali Regional State. M.Sc. Thesis, Alemaya University, Ethiopia. 
Amaha, K. 2006. Characterization of rangeland resources and dynamics of the pastoral production system in the Somali Region of Eastern Ethiopia. Ph.D. Thesis, University of Free State, Bloemfontein, South Africa.

AOAC (Association of analytical chemists). 1990. Official Method of Analysis. $15^{\text {th }}$ edition. AOAC Inc. Arlington, Virginia, USA.

Aune, J.B., Bussa, M.T., Asfaw, F.G. and Ayele, A.A. 2001. The ox ploughing system in Ethiopia: can it be sustained? Outlook on Agriculture 30: 275-280.

Barton, F.E. 1997. What three questions should I ask before using NIRS? USA, Agricultural Research Services, Richard B. Russel Agricultural Research Center, Athens.

Berihun, M. 2005. Effect of planting pattern and harvesting days on yield and quality of bana grass. M.Sc Thesis, Alemaya University, Ethiopia.

Daniel, K. 1988. Role of crop residues as livestock feed in Ethiopian highlands. In: Dzowela, B.H. (ed.). African forage plant genetic resources, evaluation of forage germplasm and extensive livestock production systems. Proceedings of the Third Pasture Network for Eastern and Southern Africa (PANESA) Workshop, 27-30 April 1987, International Conference Center, Arusha, Tanzania. pp. 430-439.

Diagnostic Survey Report. 2003. Ireland aid Ethiopia operational research and capacity building for food security and sustainable livelihoods project, July 1427, (unpublished); Addis Ababa, Ethiopia.

Ghadaki, M.B, Van Seost, P.J., McDowell, R.E. and Malekpour, B. 1975. Chemical composition and invitro digestibility of some range forage species of Iran. In: evaluation and mapping of tropical Africa rangelands, proceeding of seminar, ILCA, Bamako, Malawi.

Hassan, W. E. W., Phipps, R. H. and Owen, E. 1990. Dry matter and nutritive value of improved pasture in Malaysia. Topical Agriculture (67) 4.

Herlocker, D. 1999. Rangeland and Resource Development in East Africa. GTZ, Nairobi, Kenya.

Holechek, J.L., Pieper, R.D. and Herbel, C.H. 1998. Range Management, Principles and Practices. $3^{\text {rd }}$ edition. Prince Hall, USA.

Jahnke, E. H. 1982. Livestock Production System and Livestock. Development in Tropical Africa. Keller Wissenschaft, UAUK.

Kabaija, E. and Smith, O.B. 1988. Effect of season, fertilizer application and age of regrowth on mineral content of guinea grass (Panicum maximum, Schum) and Giant Star grass (Cynodon nlemfuensis, Chedda). In: Dzowela, B.H. (ed.). African forage plant genetic resources, evaluation of forage germplasm and extensive livestock production system. Proceedings of the Third Pasture Network for Eastern and Southern Africa (PANESA) Workshop, 27-30 April 1987, International Conference Center, Arusha, Tanzania. pp. 458-467.
Legesse, G. 2008. Productive and economic performance of small ruminants in two production systems of the highlands of Ethiopia. Ph.D. Dissertation, University of Hohenheim, Stuttgart, Germany.

McDonald, P., Edwards, R.A., Greenhalgh, J.F.D. and Morgan, C.A. 2002. Animal Nutrition. $6^{\text {th }}$ edition. Longman Group UK Ltd, England.

Minson, D.J. 1988. The chemical composition and nutritive value of tropical legumes. In: Tropical Forage Legumes, FAO, Rome, Italy. pp. 185-193.

Minson, D.J. 1990. The chemical composition and nutritive value of tropical grass. Commonwealth Scientific and Industrial Research Organization, Brisbane, Australia. In: Tropical Grasses, FAO plant production and protection series No 23, Rome (Italy). pp. 163-180.

Njunie, M.N., Reynolds, L., Mureithi, J.G. and Thorpe, W. 1993. Evaluation of herbaceous legume germplasm for coastal lowland East Africa. In: Ndikumana, J., de Leeuw, P. (eds.). Sustainable feed production and utilization for smallholder livestock enterprises in sub-Saharan Africa. Proceedings of the second African Feed Resource Network Workshop, 6-10 December, 1993, Harare, Zimbabwe. pp. 11-18.

Perkin, E. 1982. Analytic Method for Atomic Absorption Spectrophotometer. Perkin Elmer Corporation, Norwalk, Connecticut, USA.

Sarawa, M.M. and Nisa, M.U. 1999. Effect of nitrogen fertilization and stage of maturity of Mott grass (Pennisetum purpureum) on its chemical composition, dry matter intake, ruminal characteristics and digestibility in Buffalo Bulls. Asian-Australian Journal Animal Science 12: 7.

SAS (Statistical Analysis System) Institute. 1998. User's guide. Version 6.12. Carry. NC, SAS Institute Inc.

Senbeto, F. 2006. Assessment of the forage biomass, available feed resources and resource use system in Umbulo Wacho Watershed. M.Sc. Thesis, Debub University, Hawassa, Ethiopia.

Snyman, H.A. 1993. Strive to optimum field condition and grazing capacity. South Africa Koop 9:25-28.

Soni, B.K. 1975. Animal carrying capacity, including concept and definition methods for assessment and use of standard stock units. In: Evaluation and Mapping of tropical African rangelands. Proceedings of the seminar, 3-8 March 1975, Bamako, Mali.

Tilley, J.M.A. and Terry, R.A. 1963. A two-stage technique for the in vitro digestion of forage crops. The Journal of the British Grassland Society 18: 104-111.

Tsige, Y. 1999. Livestock feed security and associated impact on sustainable agricultural development. In: ESAP. Proceedings of the $7^{\text {th }}$ National Conference of the Ethiopian Society of Animal Production, 2627 May 1995, Addis Ababa, Ethiopia. pp. 51-61.

Underwood, E.J. 1981. The Mineral Nutrition of Livestock. $2^{\text {nd }}$ edition. Franham: Commonwealth Agricultural Bureau. CAB, London.

URL (Arizona Rangelands, University of Arizona). 2001. Rangeland inventory, monitoring and evaluation. 
Tegene et al.

http://rangelandswest.org/az/inventorymonitoring /biomass.html.

Van Soest, P.J and Robertson, J.B. and Lewis, B.A. 1991. Method for detergent fiber, neutral detergent fiber and non-starch polysaccharides in relation to animal nutrition. Journal of Dairy Science 74: 3583-3597.

Van Soest, P.J and Robertson, J.B. 1985. Analysis of forage and fibrous foods. A laboratory manual for animal Science. Cornell University, Ithaca, New York, USA.
East African Journal of Sciences Volume 4 (1) 1-10

Whitehead, D. 2000. Nutrient element in grassland, soilplant-animal relationships, UK University Press, Cambridge.

Whiteman, P.C. 1980. Tropical Pastures Science. Oxford University Press, New York.

Wilkins, R.J. 2000. Forages and their role in animal system, Institute of Grassland and Environmental Research, CAB International, North Wyke, and UK. 